Over the last few years, there has been burgeoning interest in men as the missing 'other half' of Gender and Development (GAD). From work in the reproductive health field on involving men, to a concern about spiralling male unemployment and the rising tide of gender-based violence, men and masculinities are now very much on the GAD agenda. Yet the shift towards considering men's identities and relations as gendered subjects has provoked ambivalence that extends beyond the debate on whether or not men as men constitute an appropriate focus for GAD activities. It raises challenges that lie at the heart of GAD as a political project and, as such, has a number of important implications for policies and practice.

This issue of the IDS Bulletin draws together a range of perspectives from people who have been active in recent debates on men and masculinities in GAD. Many of the contributors have been participants in the ongoing ESRC Seminar Series, 'Men, Masculinities and Gender Relations in Development'. ${ }^{1}$ Arising principally from presentations given at a two-day seminar on the politics of the personal at the University of East Anglia in June 1999, this issue seeks to explore some of the implications and some of the ambivalence that surrounds the new masculinities agenda. In doing so, we seek to open up the debate to other perspectives and other voices, within a terrain that is increasingly contested. This introduction draws on discussions at the UEA workshop and the articles in this issue, to highlight some of the challenges of moves to involve men in GAD.

\section{The Politics of the Personal}

The feminist slogan 'the personal is political' takes on a new resonance when looking at recent work by and with men. As Pearson (this issue) points out, second wave feminism informed a politics that inscribed the personal in the professional domain of Women in Development (WID) work and the refocusing of GAD around female subordination (see, Razavi and Miller 1995). The tide of work on male subjectivities and experiences that grew out of men's studies in the 1980s, however, has dwelt on quite different themes.

Much of this writing reworks the very dualisms that feminists have sought to challenge. It does so
Men,

Masculinities and

Development

Politics, Policies and Practice

\section{Andrea Cornwall and Sarah C. White}

IDS Bulletin Vol 31 No 22000 
through a series of reversals, from exploning men's emotions, to locating men in the domain of the domestic, to exploning the association of men with nature and the wild (see, for example, Kimmel (ed.), 1987).

In this reversed reality, questions of power tend to be eclipsed by a focus on male subjectivities. As Cornwall and Lindisfarne point out, in appropriating the personal, there has been a tendency to forget the political and ignore the vested interest many men have in resisting change' (1994:34). In the context of GAD, which has conventionally focused on the 'public' domain and on a materialist analysis within that, the call for more of a focus on men's own experiences has met with the concern that the political may well get lost altogether.

Tensions remain between an expressed need to open space for men's experiences as men and an insistence that this space be politicised, and interpreted with reference to - rather than remain outside - feminist politics. These tensions spill over into questions of engagement.

\section{Questions of Engagement}

Discussions on the politics of the personal relate directly, then, to the broad issue of whether and how GAD might engage with men.

\subsection{Bringing men in}

GAD is, and remains, a field occupied by women. And those who have been at the forefront of efforts within GAD to draw attention to the issue of men and masculinities have been largely female (Sweetman (ed.) 1997). Pearson (this issue) expresses some of the scepticism felt amongst those working in GAD about this shift towards engaging with men, an issue Chant and White (this issue) both explore in the context of development practice.

For seminar participants, 'bringing men in' to GAD raised a number of questions and challenges. Some of the men present clearly felt hurt and aggnieved at having been excluded from and silenced in gender arenas. On the other hand, some women felt protectionist and defensive: since women had done the pioneening work on GAD, what entitlement had men to step in now that gender has become 'respectable', an interest that can advance rather than scupper careers? Could men join in as coworkers, or would they inevitably seek positions of control? Is it appropriate to begin work on men, when so much remains to be achieved for women? Would this advance the interests of women, or divert attention from them?

This raises wider questions for GAD. Is a focus on men a legitimate part of the wider project of GAD? And is it an appropriate focus for allocation of resources, either in terms of time or money? Where might the trade-offs and benefits lie? And what risks might this entail? Others still raised the issue of responsibilities. Do women have the responsibility for 'bringing men in', and if so, who sets the terms for engagement? Or does extending GAD to men imply enabling men to take a more active role in shaping interventions, thereby assuming greater responsibility for efforts to change gender relations? In each scenario, who sets the agenda - and what is at stake?

A number of key themes emerge from these questions, with implications for the nature and focus of current GAD practice. There is a strong tendency for gender frameworks and interventions to become depoliticised as they have been institutionalised (see, for example, Goetz 1994). 'Bringing men in' is feared by some to further undermine feminist political agendas within GAD. The approach to gendered power relations provides a critical focus for these concerns. For example, seminar participants raised the question of whether empowerment activities would extend to men. Some would regard this as problematic, given existing associations of men with power: men ought, in these terms, to be giving up power rather than seeking empowerment. Others would regard this as a welcome shift towards a politics of identification based around a pursuit of equivalence and equity. For them, the simple equation of men with power masks the complexity of social relations in which different dynamics of inclusion and exclusion are mutually imbricated. These generate multiple resources for the expression of power and resistance, amongst men and amongst women, as well as between them. The polarised positions taken up on this issue alone indicate some of the tensions that run through discussions of how GAD might work more actively with men 


\subsection{Who gains?}

As participants pointed out, the question of who gains is more complex than it may seem. Concerns were raised about the implications of allocating already scarce resources to work with men, and the dangers of token interventions that merely reinforce the 'malestream' status quo. A focus on 'gender', as on 'women', has been shown to be vulnerable to reinterpretation away from a radical focus on overcoming women's structural disprivilege. Extending $\mathrm{GAD}$ to men might serve further to eclipse this as the primary focus.

Alternatively, others maintained, women can gain as much as men from the active involvement of men in GAD. Recognising both the power and vulnerability involved in the subject positions men take up and the variant gendered identities available to men is a step towards beginning to address issues such as male violence that are of direct concern to women. Opening up safe spaces for men to express their emotions and explore the contradictions they inhabit may help break the silence that serves to shore up particular idealised masculinities that are detrimental to women, as well as to many men.

\subsection{Debating 'inclusion'}

The debates around inclusion centre on pragmatic, as well as political concerns. What might 'inclusion' mean? In what, at which stages, at which levels? Is it simply a matter of including men in the arena as currently defined, or extending the scope of GAD to engage with specific concerns that men may have, as men? So we need to ask, what is in it for (which) men? What roles should men be playing in promoting 'gender issues' within development institutions? Some argued that men can be allies in re-politicising $\mathrm{GAD}$, in the wake of the instrumental and technical tendencies of 'gender mainstreaming' in practice. Yet others expressed a concern about where looking at complexity and inclusivity can take us, given the current structure and culture of development institutions.

In practice, it is clear that completely excluding men is not in fact an option. The statement of a GAD specialist in Kenya is indicative: 'There is nothing like a women's group at the community level because men are always part of the process' (White and Oduol 1998:28). This is confirmed by widespread evidence on the presence of men in 'women's groups' elsewhere in Africa (see Araki 1997; Crewe and Harrison 1998). This complements evidence on women's everyday negotiation of men's gender identities at the household level, in organisations and in community, local and national politics (see Staudt (ed.) 1990; White 1997). The exclusion of men in discourses on gender in GAD clearly does not reflect either the practical realities of women's lives, or even the full range of GAD intervention, in which fieldworkers refashion policy to fit the context they encounter (Goetz 1996). Like it or not, men are involved. The challenge is to find the most progressive ways to channel this involvement.

Simply 'inviting men in' without engaging with some of the concerns that they have, as men, might not provide a very inviting prospect to anyone but the most ardent pro-feminist. What is in it for men? If the scope of GAD were to extend to embrace men's concerns as men, what kinds of further tensions and polarities might this evoke in a field where the 'woman as victim, man as problem' discourse remains so pervasive (see Cornwall, White, this issue)?

\section{Men, Masculinities and GAD: Reflections and Critiques}

The articles in this bulletin take up many of these themes, providing a spectrum of different perspectives on some of the challenges evoked by a shift in focus towards the issue of men and masculinity. All address, in various ways, the question of whether and how to extend the focus of GAD to encompass work with and by men.

\subsection{Why include men?}

Sylvia Chant's article gives the most comprehensive review of the arguments for including men in GAD, summarising the key issues raised in the literature up to now, and underlined by other articles in this bulletin. Chant's analysis highlights three main lines of argument for male inclusion in GAD, raising issues that other contributors take up in more detail. First, she suggests, changing global structures of production and reproduction have weakened 'traditional' icons associated with male dominance, such as the roles of breadwinner and head of the family. The loss, in at least some areas, of accustomed gender-based privilege accruing to 
men has led to talk of men in crisis, and a new interrogation of men's identities and experiences. Such issues are not only of concern to men themselves. There is also evidence that the anger and confusion men experience may be expressed in increased violence and alcohol and/or drug abuse, with serious consequences for women and children.

Figueroa considers these issues most directly, questioning the framing and reasons behind male 'underachievement' in education in the Caribbean. Two other articles explore the subject of male violence from two very different perspectives. Poudyal attributes the prevalence of violence against women in South Asia directly to the power ascribed to men by patriarchy. He argues that exploring the diversity of masculinities in South Asia, including their points of vulnerability, can foster alternative conceptions of masculinity, particularly amongst young people. In contrast, Greig argues against the notion of accepting the boundaries of apparently fixed identities, stressing the need to consider a relational process of identification. He argues, thus, for a situated approach to the 'violent politics of difference' at the heart of masculinity, which comprises not only misogyny, but also homophobia and racism.

The second set of arguments for bringing men in are that, as GAD 'comes of age', developments in social theory challenge it to understand gender in more nuanced and interactive ways. This not only implies the need to bring men in, but also to interrogate how 'men' and 'masculinities' are defined and conceptualised. Greig's article speaks to this, first in problematising the men/masculinity homology (though he does focus only on men) and second in exploring specific instances in order to ascribe accountability, complicity and responsibility. This offers an important counterweight to Poudyal's account, showing that it is necessary not just to shift focus to 'the pain of being a man' but also to explore how that in itself represents one means of identification, and the social relations that this sustains and is sustained by.

Cornwall and White's articles both address the ways in which 'gender', 'men' and 'masculinities' are conceptualised, arguing for the need to transcend understandings of gender as 'sex dressed', as White puts it. White explores the hazards entailed by simply 'bringing men in' without a broader reflection on issues of power and difference. She argues for breaking the creeping identification of 'masculinity' with 'men' in gender writing, and so the reinscription of gender as the primary form of social difference, and of identities rather than relations as the key focus. Cornwall's analysis of the 'missing men' in GAD discourse and practice draws attention to some of the problematic implications of the ways in which 'gender', 'gender relations' and the category 'man' are currently framed. Simply 'adding men' to current forms of practice, Cornwall argues, will fail to make a difference precisely because it would leave these larger questions unaddressed.

The third set of reasons for considering men reflects dilemmas arising from the practical application of GAD. These include the negative labelling of men, which fixes them in oppositional sexed categories; the obstacles caused by male hostility to 'women only' projects; the danger that discursive privileging of women in development will result in an overload of work for them; and the importance of addressing 'the male side' of shared problems, such as sexual health or family nutrition. Cleaver argues that approaches to natural resource management have naturalised women's presumed 'superiority' in managing collective resources. This means they have failed to take adequate account either of the negotiated character of gendered rights and responsibilities, or changes in these and their perception over the life course. Greene argues that negative views of men have ironically sustained an evasion of confronting the gender inequities that inhibit reproductive health, as the focus on women clients has legitimated health professionals in working around (assumed) male hostility.

\subsection{The politics and pragmatics of including men}

As noted above, the politics of bringing men in are hotly contested. For all of the writers here, the underlying concern is to advance gender equity. Färnsveden and Rönquist argue most unequivocally for the greater inclusion of men, believing that this will raise the status of the gender project. Pearson offers the most sceptical voice, deploying controversial polarities of north/south, men/women, and political/technical to make her argument. In essence she maintains that more involvement of men will be positive only if there is a political commitment amongst men themselves for changing gender 
relations, and sees little evidence of this at present. Notes of caution are sounded somewhat differently by White, concerning the danger of reverting to existing patriarchal scripts when seeking to address 'the problem(s) of men'.

The importance of considering gender along with other factors is a recurring theme in many of the articles in this issue. Greene argues that the exclusion of men from reproductive health problems does not stand alone, but is rather an outcome of the way issues have been framed more broadly, for example in terms of 'family planning'. Both Färnsveden and Rönquist and Figueroa stress the importance of status to the options men make. With a point guaranteed to raise feminist hackles, Färnsveden and Rönquist state that increasing the status of gender within Sida would/is attract(ing) more men to get involved.

Figueroa argues rather differently that the declining status of education, and the declining cash value of the jobs for which it equips people, is one factor in working class male withdrawal of commitment to schooling. Re-focusing the issue from the simplistic proposition of 'male marginalisation', he points out that education in Jamaica is bifurcated. On the one hand it equips for top jobs in technical/scientific or senior management positions, which are still middle class and male dominated. On the other it offers a path to lower status, relatively poorly paid jobs in the formal sector, which are increasingly female dominated. Better financial returns, and possibly more attractive types of activities (irregular, risky, more suited to Jamaican 'hard male' identities) in the informal sector are therefore attracting young males from working-class backgrounds. While he analyses this as an ironic outcome of gender privileging, it could also be read as continued gender privileging, with women as the fall guy for male fun/risky economic, social and sexual projects.

The final issue concerns the pragmatics and politics of what should be done. This again generates a wide spectrum of views. Perhaps the simplest approach is to supplement the existing focus on women with a complementary focus on men. This is exemplified by Färnsveden and Rönquist in relation to the place of men in the gender equality work of Sida. Seeing relatively little need to challenge or even question male identities, their analysis displaces and serves to obscure those gendered power relations that remain a very real obstacle to gender equity. There are many resonances here with the men's studies literature, from the overprivileging of parenting within the domain of the domestic to a failure to engage with the institutional dimensions of gendered power relations within other domains, notably that of the workplace.

While more critical of present constructions of masculinity, the film project described by Poudyal is similarly very much by men on men for men, therefore identifying masculinity as a male issue, and potentially sidelining women. By contrast, Figueroa argues strongly against interventions that focus specifically on men. He maintains rather that measures should address gender differentiated outcomes of educational disadvantage through gender neutral measures - such as moves better to support all children 'failing' within the educational system. The rationale for this is robust: since the problem derives from highly differentiated gender identities, rooted in patriarchy, solutions should not reinforce these, but seek to transcend them.

A weakness of this collection is the paucity of articles that reflect on the practical experience of working with men on gender. One area, however, in which there is increasing experience is in gender training. Here the challenges of a transition in perspective become perhaps most evident, in the wake of forms of gender training that have failed to effectively address men as gendered subjects. Levy et al. draw on rich recent experience to analyse some of the lessons learnt from working with men as gender trainers. They describe the practical disadvantages of including 'token men', who become defensive and feel themselves the object of generalised attacks, put in a position where they feel they have to defend 'mankind'. One important conclusion they draw is the importance of including a 'critical mass' of men, to allow space for diversity in which men can challenge one another.

\section{Moving Forward: Practical Challenges}

Many challenges lie ahead. There is a clear need for more research into how men and women are in practice negotiating male involvement in GAD programmes, at all levels. There is equally a need for 
greater clanity about what actively promoting the involvement of men in GAD might actually look like. What kinds of policies, projects and practices would such promotion entail? What kinds of changes might be needed to current strategies to enable practitioners to focus more directly on the issues of gendered power raised by many of the contributors to this bulletin? What tactics might be needed to bring about these changes? Alongside these questions lie other more practical concerns. How might practitioners deal with the conflicting emotions that male involvement might evoke? How might the sensitivities involved be best handled? And what practical steps can be taken to tackle deep-rooted attitudes, values and beliefs in ways that recognise both women and men as gendered subjects who occupy complex and multiple positions of power and powerlessness?

One thing is clear. Without a radical overhaul of current approaches to GAD, the prospect of extending GAD to focus more directly on working with men remains fraught with difficulties. Yet the debate on whether or not men should be included in GAD brings with it an exciting new opportunity to begin to rethink current strategies and tactics. A vanety of entry points provides the scope for wider changes in policies and practices, with implications for women as well as for men. Shifts towards a development agenda in which inequalities, social justice and rights play a central part open up new spaces for engagement. Coalition building and support can create and strengthen new forms of solidanity across the gender divide. Issues of common concern - such as gender violence - can provide a means of making use of these entry points, offening the basis for dialogue at different levels.

Issues of the personal and the political come together very acutely in this area, and need to be tackled with courage and sensitivity. Without a broader recognition of the structural relations of power within which we all become who we are, there is a very real danger that efforts to bring men in' will fail to effectively confront and transform inequitable relations. To do so will require more than simply making space within GAD for male participation. Rather, it requires that we refocus our concern on the positions and relations of gendered power and powerlessness that produce and sustain inequity, seeking through this a way of moving beyond static frameworks and stereotypes towards genuinely transformatory practice.

\section{Note}

1 This is an ongoing collaborative seminar senes, coordinated by Frances Cleaver of the University of Bradford, bringing together academics and practitioners working in gender studies and development.

\section{References}

Araki, M., 1997, Women's Clubs, Associations and Other Relations in Southern Zambia: Interactions between Development Interventions and People's Own Strategies, $\mathrm{PhD}$ thesis, University of East Anglia.

Cornwall, Andrea and Nancy Lindisfarne, 1994, 'Dislocating masculinity: gender, power and anthropology', in A. Cornwall and N. Lindisfarne, eds, Dislocating Masculinity: Comparative Ethnographies, London: Routledge.

Crewe, Emma and Elizabeth Harrison, 1998, Whose Development? An Ethnography of Aid, London: Zed Books.

Goetz, Anne-Marie, 1996, 'Local heroes: patterns of fieldworker discretion in implementing GAD policy in Bangladesh', IDS Discussion- Paper No. 358, Brighton: IDS.

Goetz, Anne-Marie, 1994, 'From feminist knowledge to data for development: the bureaucratic management of information on women and development', IDS Bulletin, Vol. 25, No. 2:27-36.

Kimmel, Michael, 1987, Changing Men: New Directions in Research on Men and Masculinity, California: Sage.

Razavi, Shahrashoub and Carol Miller, 1995, 'From WID to GAD: conceptual shifts in the women and development discourse', Occasional Paper, No. 1, Geneva: UNRISD.

Staudt, K., ed., 1990, Women, International Development, and Politics: The Bureaucratic Mire, Philadelphia: Temple University Press.

Sweetman, Caroline, ed., 1997, Men and Masculinity, Oxford: Oxfam.

White, Sarah, 1997, 'Men, masculinities and the politics of development', Gender and Development, Vol. 5, No. 2:14-22.

White, S. and J. Oduol, 1998, DFID Kenya Gender Audit, mimeo, London: DFID. 